\title{
IX. IN MEMORIAM
}

\section{Wiesław Daszkiewicz (1927-2013)}

W dniu 13 sierpnia 2013 r. zmarł po długiej chorobie Wiesław Daszkiewicz, emerytowany profesor zwyczajny Uniwersytetu Mikołaja Kopernika w Toruniu i Uniwersytetu im. Adama Mickiewicza w Poznaniu. Był wybitnym uczonym o rozległej skali zainteresowań twórczych. Należał do wąskiego grona najbardziej cenionych badaczy procesu karnego w Polsce. Wnosił do swojej dyscypliny i do całego prawoznawstwa niemały ładunek wiedzy teoretycznej. Wykazywał głęboką znajomość historii prawa. Jego teksty wypełniały także łamy „Czasopisma Prawno-Historycznego”. Uczestniczył aktywnie w życiu naukowym, był świetnym nauczycielem akademickim, odznaczał się skromnością, życzliwością dla otoczenia, wyróżniał wysokimi wymaganiami, także w stosunku do siebie.

Urodzony w 1927 r. w Aleksandrowie Kujawskim, studiował prawo na Uniwersytecie Mikołaja Kopernika (1947-1951). Po ukończeniu studiów rozpoczął akademicką drogę w Katedrze Postępowania Karnego UMK, u profesora Stefana Kalinowskiego. Po zamknięciu Wydziału Prawno-Ekonomicznego w Toruniu został służbowo przeniesiony na Uniwersytet Poznański. Tu doktoryzował się na podstawie rozprawy Ingerencja prokuratora $w$ sprawy prywatnoskargowe w polskim procesie karnym (1959) i uzyskał stopień docenta na podstawie monografii Oskarżyciel w polskim procesie karnym (1960). Po krótkim okresie zatrudnienia w Instytucie Państwa i Prawa Polskiej Akademii Nauk powrócił na reaktywowany wydział macierzysty w Toruniu, na którym został kierownikiem Katedry Postępowania Karnego oraz dyrektorem Instytutu Prawa Sądowego UMK i jako profesor nadzwyczajny (1967) i zwyczajny (1973) zyskał naukową sławę. W ostatnich latach przed przejściem na emeryturę pracował na Uniwersytecie im. Adama Mickiewicza.

Renomę Profesora ugruntowywała jego aktywność organizacyjna: Wiesław Daszkiewicz był członkiem Komitetu Nauk Prawnych PAN, uczestniczył w pracach Centralnej Komisji Kwalifikacyjnej do spraw Kadr Naukowych, był członkiem Rady Legislacyjnej przy Prezesie Rady Ministrów i członkiem Komisji do spraw Reformy Prawa Karnego. Redagował „Przegląd Prawa 
Karnego", zasiadał w kolegiach redakcyjnych renomowanych periodyków prawniczych: „Państwo i Prawo”, „Ruch Prawniczy, Ekonomiczny i Socjologiczny”, „Studia Iuridica”, „Orzecznictwo Sądów Polskich”. Przez blisko 20 lat prowadził stały przegląd orzecznictwa na łamach „Państwa i Prawa”. Naukowy autorytet zawdzięczał oczywiście nade wszystko publikowaniu wyników prowadzonych badań. Był autorem kilkuset prac: monografii, studiów i rozpraw, recenzji i glos. Wysoko ceniono jego monografie: Proces adhezyjny na tle prawa polskiego (1962), Zasadzenie odszkodowania z urzędu w polskim procesie karnym (1970), Naprawianie szkody w polskim prawie karnym (1972), Przedstawiciel spoleczny w prawie karnym (1976), Powództwo cywilne $w$ procesie karnym (1976). Prace te wywarły ewidentny wpływ na funkcjonowanie istniejących instytucji procesu karnego w kraju. Jego podręcznik akademicki procesu karnego cieszył się wielką popularnością na uniwersytetach polskich i był kilkakrotnie wznawiany.

Profesor Wiesław Daszkiewicz był także znanym historykiem prawa. Podejście historyczne do badanej materii przenikało większość Jego prac. Historię traktował jako drogę prowadzącą do współczesności i kształtującą przyszłość. Zafascynowanie historią prawa widoczne było szczególnie w początkach Jego drogi naukowej, w latach pięćdziesiątych, a rezultaty rozległych kwerend ogłaszał na łamach „Czasopisma Prawno-Historycznego" w latach pięćdziesiątych ubiegłego stulecia. Podejmował tematy ważne i trudne, wcześniej leżące odłogiem i kontrowersyjne: badał historię procesu karnego w Księstwie Warszawskim i Królestwie Polskim i w poszczególnych zaborach; poddawał analizie postępowanie w procesach karnych Polski Odrodzonej w 1918 r. Wiesław Daszkiewicz pisał w czasach złych i nieprzyjaznych, w których polityka i ideologia szerokim strumieniem wlewały się do nauki, co nie sprzyjało rzetelnym studiom historycznoprawnym. Jak wielu innych prawników i historyków badających dzieje polskie XIX wieku i II Rzeczypospolitej młody badacz nie uniknął interpretacji, które stanowiły signum temporis swojej epoki. W jego wywodach można zauważyć obecność schematycznego pojmowani uwarunkowań procesu historycznego, właściwego podówczesmu kanonowi marksizmu. Jak wielu bardziej wytrawnych badaczy spoglądał na dzieje przez pryzmat ,porządku klasowego”. W obszernym studium o Próbach reform procesu karnego w Królestwie Polskim przedstawiał akty normatywne w zakresie procedury karnej oraz projektów reform w tej dziedzinie na tle przemian społecznych XIX stulecia. W Projekcie procedury dla przysiegłych z 1819 r. upatrywał przejaw myśli ograniczonej klasowo, ale przecież demokratycznej. W poszukiwaniu postępu w dziejach często zatrzymywał się nad sądami przysięgłych. Ciekawe spojrzenie ujawniał najmocniej w analizie idei Kodeksu karnego dla Gwardii Narodowej Warszawskiej z roku 1830. Dostrzegał w nim propozycję obcą z powodu burżuazyjnego składu ławy przysięgłych, ale wyrażającą postęp. Klasowo zdeterminowane oceny 
cechowały też publikowane na łamach $\mathrm{CPH}$ teksty o postępującym procesie faszyzacji wymiaru sprawiedliwości w II Rzeczypospolitej. Autor stwierdzał - zgodnie z oficjalną doktryną polityczną, że faszyzacja procesu karnego następowała wraz z faszyzacją państwa, na drogę której burżuazja wkroczyła w 1926 r., a zatem jeszcze przed wydaniem jednolitego dla całego państwa kodeksu postępowania karnego. Podkreślał, że „faszyzacja procesu karnego w Polsce" wyrażała się nie tylko w ograniczaniu i stopniowym likwidowaniu prawa do obrony. Znajdowała też odbicie w dziedzinie postępowania przygotowawczego, ustroju sądów, środków odwoławczych, praw i obowiązków prokuratury oraz uprawnień pokrzywdzonego.

Mimo ideologicznych przerysowań w przedstawianym obrazie badanej materii, Autor dawał teksty o sporych walorach poznawczych, oparte na rozległych kwerendach archiwalnych i bibliotecznych, uwzględniające akty prawne i praktykę sądową w powiązaniu z kwestią społeczną i prawami człowieka, podejmujące próby ujęć prawno-porównawczych. Do dziś zachowały one naukową wartość. 



\section{Marian Lech Klementowski (1943-2013)}

Dr habilitowany, profesor UMCS Marian Lech Klementowski urodził się 19 kwietnia 1943 r. w Ustianowej w powiecie Ustrzyki Dolne. Pochodził z rodziny inteligenckiej - ojciec jego był sędzią, a matka nauczycielką. Maturę uzyskał w I Liceum Ogólnokształcącym im. Stanisława. Konarskiego w Rzeszowie w $1960 \mathrm{r}$. W tymże roku rozpoczął studia prawnicze w Uniwersytecie Marii Curie-Skłodowskiej, które ukończył pięć lat później z wynikiem bardzo dobrym. Już w trakcie nauki uniwersyteckiej ujawnił wyraźne zainteresowanie historią prawa, zwłaszcza powszechną, uczestnicząc w seminarium prowadzonym przez doc. dr. hab. Witolda Sawickiego, wybitnego znawcę dawnego prawa, szczególnie w kręgu niemieckiego średniowiecza. Pod Jego kierunkiem przygotował pracę magisterską w 1965 r., zatytułowaną ,Zemsta legalna jako forma wymiaru sprawiedliwości w państwie niemieckim za panowania dynastii saskiej (919-1024)". Po ukończeniu studiów, w latach 1965-1967 odbył aplikację sądową i w 1967 r. złożył egzamin sędziowski.

Od października 1965 r. rozpoczął w UMCS pracę naukowo-dydaktyczną, w ówczesnej Katedrze Powszechnej Historii Państwa i Prawa kierowanej przez doc. dr. hab. W. Sawickiego. Z dyscypliną tą związał się M.L. Klementowski na stałe, choć sama Katedra ulegała kolejnym przekształceniom organizacyjnym oraz personalnym. Przeszedł kolejne stopnie akademickiej kariery - od asystenta stażysty po stanowisko profesora nadzwyczajnego UMCS, do ostatnich swych dni będąc zatrudniony w Katedrze Historii Państwa i Prawa. Naukowy debiut M.L. Klementowskiego miał miejsce w 1968 r. artykułem poświęconym ograniczeniu zemsty przez prawo niemieckich pokojów ziemskich od XI do połowy XIII wieku, opublikowanym w „Annales UMCS" (sec. G, vol. XV), a w czerwcu 1973 r. odbyła się na Wydziale Prawa i Administracji UMCS obrona Jego rozprawy doktorskiej pt. „Wymiar sprawiedliwości karnej według prawa niemieckich pokojów ziemskich w XI - do połowy XIII wieku" (Lublin 1972, mpis, ss. XX+409+222). Napisał ją pod kierunkiem doc. dr. hab. W. Sawickiego, który zmarł w maju tegoż 1973 r., a formalnie funkcję promotora przejął prof. dr hab. Jan Malarczyk. Recen- 
zentami w przewodzie doktorskim byli profesorowie Wojciech Maria Bartel z Uniwersytetu Jagiellońskiego i Leszek Winowski z Uniwersytetu Wrocławskiego.

Od lat 70. XX wieku centralnym obszarem badawczym profesora Klementowskiego pozostawały dzieje prawa karnego, zarówno materialnego jak i procesowego epoki średniowiecza oraz początków czasów nowożytnych do XVI stulecia, zwłaszcza w państwa niemieckich, na rozległym obszarze ówczesnej Rzeszy. W tej mierze Jego studia charakteryzowały się zawsze solidną podstawą źródłową, z głębokimi analizami pokojów ziemskich (Landfrieden) na czele. W miarę upływu czasu M.L. Klementowski poszerzał swój krąg badawczy tak w sensie rzeczowym jak i terytorialnym, obejmując prawie całą Europę. Stąd ujęcie porównawcze stało się mocną stroną Jego prac naukowych. Obok studiów stricte prawno-karnych, zwłaszcza w sferze średniowiecznych pojęć przestępstwa oraz kary publicznej, M.L. Klementowski zajął się problematyką gwarancji ochrony osobistej w średniowiecznych prawach europejskich. Na tym drugim polu badawczym wnikliwe i szczegółowe badania doprowadziły Go do opublikowania książki pt. Studia nad kształtowaniem się gwarancji ochrony wolności osobistej w państwie niemieckim $(X-X I V$ wiek), Lublin 1994, ss. 251, będącej rozprawą habilitacyjną. W studium tym, opartym na szerokiej bazie źródłowej, podjął problem nieopracowany w literaturze naukowej ani polskiej, ani obcojęzycznej, zwłaszcza niemieckiej. Przekonywająco sformułował tezę, iż początków powszechnej zasady nietykalności osobistej i innych gwarancji wolnościowych doszukiwać się należy już w prawie średniowiecza, a nie dopiero w doktrynach prawnych wieku Oświecenia.

Stopień naukowy doktora habilitowanego M.L. Klementowski uzyskał 30 listopada 1994 r. na podstawie uchwały Rady Wydziału Prawa i Administracji UMCS. Recenzje w przewodzie habilitacyjnym przygotowali profesorowie Adam Lityński z Uniwersytetu Śląskiego, Kazimierz Orzechowski z Uniwersytetu Wrocławskiego oraz Artur Korobowicz z UMCS. Od razu dodajmy, iż pięć lat później (od 1.10.1998 r.) dr hab. M.L. Klementowski otrzymał stanowisko profesora nadzwyczajnego UMCS.

Recenzenci dorobku naukowego M.L. Klementowskiego zgodnie podkreślali, iż efekty badawcze Jego studiów nad średniowiecznym prawem karnym udowodniły, że jest On wytrawnym badaczem tej epoki, swobodnie poruszającym się w skomplikowanej i obszernej problematyce. Jego opracowania przyniosły bowiem nie tylko liczne nowe ustalenia, głębokie oraz precyzyjne, poszerzające naszą znajomość ówczesnego prawa i procesu karnego, ale też zawierały wyraźne treści teoretyczne idące w stronę syntez oraz jednoznacznych tez naukowych. Lapidarnie i celnie oceniał wartość publikacji Adam Lityński: „bez prac Klementowskiego nikt nie może dzisiaj w Polsce pisać o prawie karnym średniowiecza, niezależnie od terytorium, którym się zajmu- 
je”. Dodać trzeba, iż publikacje M.L. Klementowskiego wzbudziły zainteresowanie w nauce niemieckojęzycznej i dzięki publikacjom w ,Zeitschrift der Savigny-Stiftung für Rechtsgeschichte" (CXXVI Band, Germanistische Abteilung, Wien-Köln-Weimar, 1966) weszły do obiegu międzynarodowego.

Podjął również profesor Klementowski zagadnienia historii dawnego prawa polskiego. Początek tym zainteresowaniom dał artykuł o zniesieniu tortur w Polsce (we współautorstwie z E. Skrętowiczem), jak i interesujące prace o sądownictwie w Ordynacji Zamojskiej. Problematyce ustroju, norm prawnych i kultury prawnej regionu zamojskiego w Polsce szlacheckiej poświęcił M.L. Klementowski kolejne publikacje. Pisał, źródłowo i erudycyjnie, o wymiarze sprawiedliwości w Ordynacji Zamojskiej, o relacjach między instytucjami ordynackimi a Akademią Zamojską, jak również o sejmikach chełmskich w XVII stuleciu. Studia te, oprócz niewątpliwych wartości regionalnych, w istotny sposób wzbogaciły naszą wiedzę i mają wymiar szerszy, ogólnopolski, tak jak i instytucje prawne państwa zamojskiego stanowiły ważki fragment rzeczywistości ustrojowo-prawnej dawnej Rzeczypospolitej. Wystarczy przypomnieć Akademię Zamojską i jej rolę (zwłaszcza na wschodzie Polski) w kształceniu prawników, będącą tak długo, obok Krakowskiej, funkcjonującą szkołą wyższą. W 2002 roku ukazała się Bazylego Rudomicza Efemeros, czyli Diariusz prywatny pisany w Zamościu w latach 1656-1672 (Lublin, UMCS). To duże, dwutomowe wydawnictwo źródłowe, liczące łącznie blisko 1000 stron, było efektem iście benedyktyńskiej pracy dwóch autorów: M.L. Klementowskiego (opracowanie historyczne i historycznoprawne) oraz Władysława Frocha (przekład z języka łacińskiego i opracowanie filologiczne). „Wysiłek godny podziwu i najwyższego uznania” - jak pisał o nim A. Lityński - ,efekt naukowy poważny: wzorowo wydany ogromny diariusz, naukowo opracowany, stał się na zawsze pomnikiem prawa, polityki, obyczajów, powszechnie dostępny historykom". Sylwetce Bazylego Rudomicza i jego działalności w Zamościu poświęcił też M.L. Klementowski różnorakie rozprawki szczegółowe.

W ostatnich latach prof. Klementowski ciągle twórczo pracował, publikując w uprawianych przez siebie obszarach badawczych, m.in. rekapitulacyjne studium poświęcone kształtowaniu się gwarancji ochrony wolności osobistej w średniowieczu i nowożytnej Europie. Zajmował się także ciekawą problematyką odpowiedzialności karnej zwierząt. Szereg Jego opracowań o charakterze przekrojowym, dotyczących zagadnień zemsty prywatnej praz kar publicznych, jak też studiów nad sądownictwem i prawem w Ordynacji Zamojskiej w XVI-XVIII wieku, pozostało w maszynopisie.

W akademickiej pracy dydaktycznej M.L. Klementowski prowadził zajęcia z powszechnej historii państwa i prawa (jak i w swoim czasie historii ustroju Polski na tle powszechnym) we wszystkich formach kształcenia: od ćwiczeń poprzez wykłady do proseminariów i seminariów magisterskich. Był 
nauczycielem akademickim niezwykle odpowiedzialnie traktującym swoje obowiązki dydaktyczne, rzetelnym i przyjaznym studentom, umiejętnie przekazującym młodzieży swoją bogatą wiedzę. Na swoje seminaria przyciągał propozycjami rozległej tematyki prac magisterskich, sięgającej od epoki średniowiecza po wydarzenia XX stulecia i wiążącej zagadnienia historycznoprawne z ogólnymi dziejami państw i społeczeństw (Niemcy, Rosja sowiecka, polskie Kresy Wschodnie). Pod Jego kierunkiem napisano blisko 300 prac magisterskich. Ukoronowaniem doświadczeń dydaktycznych stał się podręcznik Jego autorstwa pt. Powszechna historia ustroju opublikowany w Wydawnictwie Naukowym PWN (Warszawa 2012) w serii naukowej pod redakcją prof. dr. hab. Mariana Kallasa. Liczące 735 stron dzieło, mające charakter ogólnopolski, zawiera dzieje ustrojów państwowych od upadku zachodniego cesarstwa rzymskiego po system państwowy Niemiec, ZSRR i Francji po II wojnie światowej. Obejmuje terytoria Francji, Anglii, Niemiec, w tym Prus i Austrii, Rosji oraz Stanów Zjednoczonych Ameryki, a także ekspansji kolonialnej tych mocarstw. Cechuje go ujęcie instytucjonalne, łącznie z przedstawieniem dynamicznego rozwoju historycznego, oparcie treści na wynikach najnowszych ustaleń naukowych, a także należyte uwypuklenie problematyki państwa konstytucyjnego oraz reżimów totalitarnych w XX wieku. Nie bez podstaw można sądzić, iż podręcznik autorstwa M.L. Klementowskiego zajmie należne mu miejsce w kanonie książek akademickich. Profesor Adam Lityński, który dobrze znał i wysoko oceniał twórczość M.L. Klementowskiego, na łamach „Czasopisma Prawno-Historycznego” (T. 65, z. 2013) zamieścił obszerną i pochlebną recenzję tegoż podręcznika, akcentując walory merytoryczne jak i pisarskie wynikające $\mathrm{z}$ głębokiego znawstwa problematyki oraz erudycji Autora. Recenzent stwierdził jednoznacznie:

„O nadzwyczajnie bogatych treściach tego ogromnego dzieła wypada mówić tylko w słowach nadzwyczajnie pochwalnych. To wielka sztuka napisać tak wielką książkę, tak jak to uczynił M.L. Klementowski: przekazać ogromną wiedzę, mnóstwo faktów, skojarzeń, w tak przejrzystej, klarownej formie, prostym językiem. Uważam, że umiejętność pisania w sposób jasny to wielka umiejętność i wszyscy uczeni powinni dokładać starań, by takie było ich pisanie. Tym bardziej powinno, a wręcz musi to dotyczyć podręcznika. Książkę M.L. Klementowskiego - mimo odstraszającej objętości - chce się czytać i niech to będzie traktowane jako wielki komplement dla Autora.

Prowadził też profesor Klementowski seminarium doktorskie. W jego ramach był promotorem czterech rozpraw, a sfinalizowania kolejnej, już przygotowanej, niestety nie doczekał.

Łącznie Jego dorobek naukowy obejmuje blisko 50 opracowań. Jest to dorobek znaczący, zważywszy na wieloletnie problemy zdrowotne i związane z tym liczne utrudnienia i przeciwności w toku czynnej pracy zawodowej. 
Za swą działalność odznaczony został Brązowym Krzyżem Zasługi (1983), a następnie Krzyżem Złotym (1987), jak również Medalem Komisji Edukacji Narodowej (2013).

Z końcem roku akademickiego 2012/13 profesor M.L. Klementowski przeszedł na emeryturę, nie zrywając więzi z macierzystym Uniwersytetem i Katedrą Historii Państwa i Prawa. Miał zaplanowane zajęcia dydaktyczne z przedmiotu powszechna historia prawa, planował też dalszą opiekę nad doktorantami oraz własne prace badawcze. Niestety, nagle zakończył życie w dniu 27 listopada 2013 r.

W środowisku historyków prawa Uniwersytetu Marii Curie-Skłodowskiej przygotowaliśmy tom studiów, pomyślany jako jubileuszowy na 70-lecie urodzin M.L. Klementowskiego. Ukazał się już po śmierci Profesora jako XIX tom „Studia Iuridica Lublinensia”, w którym jest też bibliografia Jego prac. Stał się ów tom zbiorem rozpraw poświęconych pamięci cenionego historyka prawa i nauczyciela akademickiego, naszego Drogiego Kolegi oraz Współpracownika, człowieka szlachetnego i życzliwego. Publikacja ta niech będzie trwałym wyrazem pamięci środowiska, nie tylko lubelskiego, w którym przyszło żyć i pracować M.L. Klementowskiemu, jak też dowodem należnego Mu od nas uznania za wszystkie dokonania w Jego blisko 50-letniej działalności akademickiej. 
